\title{
$\mathrm{POE}$ 오일 나노유체의 열물성과 분산성 평가를 위한 실험적 연구
}

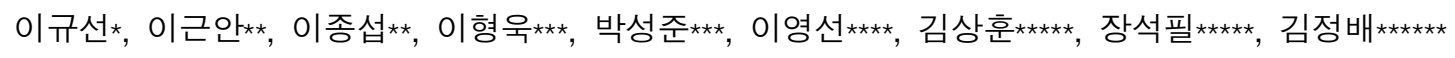

*한국교통대학교 석사과정, **한국생산기술연구원, ***한국교통대학교, ****KIMS 재료연구소,

*****한국항공대학교, ******한국교통대학교(jeongbae_kim@ut.ac.kr)

\section{Experimental Study on Dispersion and Thermal Properties of Nanofluids based on POE Oil}

\author{
Lee, K. S.* Lee, K. A.** Lee, J. S.** Lee, H. Y.*** Park, S. J.*** Lee, Y. S.**** Kim,

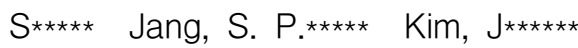

*Korea National University of Transportation, **Korea Institute of Industrial Technology, $* * *$ Korea National University of Transportation, ****Korea Institute of Materials Science, $* * * *$ Korea Aerospace University, ******Korea National University of Transportation(jeongbae_kim@ut.ac.kr)

\section{Abstract}

To apply the nanofluids into the general vapor compression cycle, basically have to know the thermal properties including thermal conductivity and dynamic viscosity. And needs to show the dispersion characteristics for various nanofluids and concentrations.

So, firstly this study showed experimentally the thermal properties for various concentration $(0.1 \% \sim 0.7 \%$, as mass balance) and temperature $\left(20^{\circ} \mathrm{C} \sim 40^{\circ} \mathrm{C}\right)$ on $\mathrm{Al}_{2} \mathrm{O}_{3}, \mathrm{TiO}_{2}$, and $\mathrm{CuO}$ nanofluids using base fluid as $\mathrm{POE}$ oil that has used in the scroll compressor for various refrigeration system. From the results, the dynamic viscosity of nanofluids was considerably changed from the base POE oil.

And, the dispersion characteristics of various nanofluids using the simple methods like as analyzing the RGB value or measuring the sinking height of nanofluids were showed experimentally. Through the results, the dispersion characteristics of $\mathrm{Al}_{2} \mathrm{O}_{3}$ nanofluid was better than those of $\mathrm{TiO}_{2}$, and $\mathrm{CuO}$ nanofluids not considering the real refrigeration cycle running conditions.

Keywords : 나노유체(Nanofluids), 분산(Dispersion), 열물성(Thermal property), 냉동사이클(Refrigeration cycle), 냉동기 오일(POE oil)

submit date : 2012. 4. 19, judgment date : 2012. 4. 24, publication decide date : 2012. 6. 12 communication author : Kim, Jeongbae(jeongbae_kim@ut.ac.kr) 


\section{1. 서 론}

난방 혹은 냉방을 위한 다양한 에너지시스 템의 사이클로 적용되고 있는 냉동사이클에 있어서의 성능은 $\mathrm{COP}$ 로 평가되어 진다. 냉동 사이클의 $\mathrm{COP}$ 는 증발열량을 압축기의 소요 동력으로 평가할 수 있는데, 특히 R-134a 냉 매와 $\mathrm{POE}$ 오일을 사용하는 냉동사이클에 질 량분율 $0.1 \%$ (오일 봉입량 기준) $\mathrm{TiO}_{2}$ 나노입 자를 으로 적용하여 에너지 소비를 $26.1 \%$ 줄 였다고 제시하고 있다 ${ }^{1)}$.

또한, 동일한 논문에서 R-134a을 적용한 냉동사이클에 $\mathrm{Al}_{2} \mathrm{O}_{3}$ 와 $\mathrm{CuO}$ 등의 나노입자를 적용하여 성능을 향상시킨 결과들을 정리하 여 제시하고 있다 ${ }^{1)}$. 그러나 $\mathrm{POE}$ 오일을 모유 체로 하는 나노유체의 열물성치에 대해서는 전혀 소개하지 못하고 있다.

1990년대 후반에 국내에 소개된 나노입자는 물을 모유체로 하여 $\mathrm{TiO}_{2}$ 나노유체를 이용하 여 $^{2)}$ 혹은 다양한 나노유체 ${ }^{3)}$ 에 대한 풀핵비등 에서의 $\mathrm{CHF}$ 증가를 실험적으로 제시하였다.

이러한 실제 시스템의 적용을 위한 기초 연 구 이후에 나노유체의 열유동 특성과 열물성 치 측정의 정도를 높이기 위한 연구를 본격적 으로 추진하였고, 비정상열선법으로 나노유 체의 열전도도 측정의 표준화 및 제타전위를 측정할 수 있는 LUMiFUGE라는 장비를 이 용하여 나노유체 내에서 나노입자의 분산성 을 평가하는 방법을 구축하였다 ${ }^{4)}$.

이러한 나노입자의 분산성은 UV-vis 스펙 트럼을 이용하여 평가하거낟) LUMiFUGE를 이용하여 제타전위를 측정하고, 이의 결과로 평가하는 방법 ${ }^{6)}$ 등을 제시하고 있다. 그러나, 이러한 방법들은 결국 고가의 장비를 이용하 여야 하고, 실제 시스템 적용하는 경우에는 별도의 분산성 실험을 수행하여야 한다.

특히, 본 연구에서 검토한 $\mathrm{Al}_{2} \mathrm{O}_{3}, \mathrm{TiO}_{2}$, 및 $\mathrm{CuO}$ 를 $\mathrm{POE}$ 오일을 모유체로 하여 나노유체 를 만들고, 이 유체를 LUMiFUGE를 이용하
여 분산안정을 평가하려 하였으나 오일의 특 성상 측정의 어려움이 있어 별도의 단순한 방 법이 필요하였다.

이에, 본 연구에서는 지금까지 명확하게 측 정되어 제시되지 않았던 $\mathrm{POE}$ 오일을 모유체 로 하고 앞서의 세 가지 나노입자를 적용한 나노유체의 열전도도 $(\mathrm{k})$ 와 동점성계수(v)를 중량비별로 측정하여 그 결과를 세계에서 처 음으로 제시하고, 또한 세 가지 나노유체의 최대 농도에서 분산성을 단순한 방법으로 평 가하여 그 결과를 제시하고자 한다.

다양한 제조방법과 제조사에서 나노입자를 생 산하고 있지만, 실제 시스템 적용을 위해 필요한 상용성과 안정성을 고려하여 세 가지 나노입자는 동일한 제조회사의 상용제품인 Sigma-Aldrich 사의 $13 \mathrm{~nm}$ 크기의 $\mathrm{Al}_{2} \mathrm{O}_{3}$ (번호:718475), $21 \mathrm{~nm}$ 크 기의 $\mathrm{TiO}_{2}$ (번호:718467) 및 최대 $50 \mathrm{~nm}$ 크기 의 $\mathrm{CuO}$ (번호:544868)을 이용하였다.

\section{2. 실험 개요 및 방법}

\section{1 나노유체 제조 방법}

나노유체 제조 방법은 기존의 연구결과세 서 제시하는 방법에 의거하여 다음과 같은 과 정에 따라 제조하였다.

(1) $\mathrm{POE}$ 오일과 나노 입자를 제조하고자 하는 중량비의 농도로 혼합

(2) 용기를 손으로 가볍게 흔들어서 믹싱

(3) 소니케이터를 이용하여 소닉

- 소니케이터에 용액 용기를 넣은 후, 물을 용액의 높이만큼 넣어준 후 가동시작

- 전체 소닉 2 시간

- 장치 특성상 한번 소닉 시간이 최대 30 분이므로, 30 분에 한번 씩 물을 교체하 면서 30 분 단위로 4 회 실시

\section{2 나노유체 열물성 측정}

나노유체의 열전도도 $(\mathrm{k}, \mathrm{W} / \mathrm{mK})$ 를 측정하 기 위해서 비정상 열선법(Transient hot wire 
method)을 이용하였다.

실험 장치는 한국항공대학교의 실험장치를 이용하였고, 모유체인 $\mathrm{POE}$ 오일을 이용하여 검증되었다. $20^{\circ} \mathrm{C}$ 에서 $40^{\circ} \mathrm{C}$ 까지의 범위에서 측정 결과 모유체 제작 업체로부터 제공된 측 정값과 $\pm 1.17 \%$ 범위 내로 측정됨을 확인하였다.

나노유체의 동점성 계수 $\left(\mathrm{v}, \mathrm{mm}^{2} / \mathrm{sec}\right)$ 는 한국 항공대학교에서 보유중인 Brookfield사의 LVDV-II Ultra Rheometer cone-plate 타입을 이용하여 측정하였다. 점도계는 회전형 점도계(Rotational Rheometer)로 측정 원리는 유체에 잠겨있는 스핀들(Spindle)이 회전하기 위하여 필요한 전단응력(Torque)을 측정하여 점성 계수를 구하는 것이다. (열전도도와 동점성계수 측정 을 위한 자세한 장치에 대한 설명과 측정 원 리는 Reference ${ }^{7)}$ 참조)

본 연구에서 제작된 나노유체의 동점성 계 수를 측정하기에 앞서 모유체인 $\mathrm{POE}$ 오일을 이용하여 검증되었다. $20^{\circ} \mathrm{C}$ 에서 $40^{\circ} \mathrm{C}$ 까지의 범위에서 측정 결과 모유체 제작 업체로부터 제공된 측정값과 $\pm 2.62 \%$ 범위 내로 측정됨을 확인하였다.

나노유체의 물성측정은 실제 냉동사이클에 적용되는 모유체 질량 기준으로 나노입자의 응집성이 이미 검증이 되어 물성 측정이 어려 운 $\mathrm{CuO}$ 를제외한 $\mathrm{Al}_{2} \mathrm{O}_{3}$ 와 $\mathrm{TiO}_{2}$ 에 대하여 나 노입자의 질량비가 $0.1 \%, 0.4 \%$ 및 $0.7 \%$ 범위 에서 열물성 측정 실험을 수행하였다. 선택된 질량비는 기존의 연구들 ${ }^{1)}$ 에서 적용한 비율의 범위를 고려하여 결정된 것이다.

\section{3 나노유체 분산성 측정}

나노유체에 분산된 나노입자의 분산성을 측정하는 기존의 방법과 달리 단순한 방법을 적용하고자 하였다.

우선 물성 측정에서 가장 높은 질량비인 $0.7 \%$ 조건에서 $\mathrm{Al}_{2} \mathrm{O}_{3}, \mathrm{TiO}_{2}$ 및 $\mathrm{CuO}$ 로 각각 만들어진 나노유체를 투명 용기에 담아, 시간 에 따라 사진을 촬영하고, 촬영된 사진에서
나노유체의 RGB값을 분석하여 침전 특성을 정량적으로 제시하고자 하였다.

나노유체의 침전 특성을 다른 방법으로 제 시하기 위하여 시간의 변화에 따라 사진을 촬 영하고, 촬영된 사진으로부터 침전되는 높이 $\left(\mathrm{h}_{\mathrm{sink}}\right)$ 를 측정하여 용기내의 초기 나노유체 높이 $\left(\mathrm{h}_{0}\right)$ 와의 비를 구하고 나노입자별로 비교 하였다.

또한, $\mathrm{POE}$ 모유체에 대한 세가지 나노입자 의 분산안정성을 이론적으로 상대 평가하는 데 아래의 식 $(1)^{8)}$ 을 이용하여 계산하고 그 결 과를 실험과 비교하여 제시하였다. 식에서 분 산안정성 $(\mathrm{G}$, 무차원 $)$ 는 중력에 의한 침전을 나타내는 분자항과 열적유동에 의한 힘을 나 타내는 분모항의 비인 무차원 수이며, $r$ 은 입 자의 반경, $\rho$ 는 밀도, $\mathrm{g}$ 는 중력가속도, $k_{B}$ 는 볼츠만 상수, $\mathrm{T}$ 는 절대온도를 나타낸다. 또 한, 하첨자 $\mathrm{p}$ 와 bf는 각각 나노입자와 모유체 를 나타낸다.

$$
G=\frac{4 \pi r^{4}\left(\rho_{p}-\rho_{b f}\right) g}{3 k_{B} T}
$$

$\mathrm{G}$ 가 1 보다 작게 되면 열적 유동특성에 따 라 발생되는 힘에 의하여 입자가 안정적으로 분산될 수 있음을 의미한다고 알려져 있다 ${ }^{8)}$.

\section{3. 실험결과 및 고찰}

\section{1 열물성 측정 결과}

본 연구에서 고려하는 나노입자 중에서 $\mathrm{CuO}$ 는 기존의 연구결과들에서 응집성이 문제가 되 어 열물성의 측정이 용이하지 않아 배제하였다. 따라서, 본 연구에서 열물성을 측정한 조건 은 $\mathrm{POE}$ 오일을 모유체로 하는 $\mathrm{Al}_{2} \mathrm{O}_{3}$ 와 $\mathrm{TiO}_{2}$ 입자를 가진 나노유체에 대하여 온도 범위는 $20^{\circ} \mathrm{C}, 30^{\circ} \mathrm{C}$ 와 $40^{\circ} \mathrm{C}$ 까지, 농도는 질 량비로 $0.1 \%$, $0.4 \%$ 와 $0.7 \%$ 에 대하여 열전도도와 동점성계 수를 측정하였다. 
Table 1. Thermal conductivity results of $\mathrm{Al}_{2} \mathrm{O}_{3}$ Nanofluids.

\begin{tabular}{|c|c|c|c|c|}
\hline \multirow{2}{*}{$\mathrm{k}[\mathrm{W} / \mathrm{mK}]$} & \multicolumn{3}{|c|}{ 온도 $\left[{ }^{\circ} \mathrm{C}\right]$} \\
\cline { 3 - 5 } & 20 & 30 & 40 \\
\hline \multicolumn{2}{|c|}{$\mathrm{POE}$ maker } & 0.1204 & 0.1198 & 0.1191 \\
\hline $\begin{array}{c}\text { 질 량비 } \\
{[\%]}\end{array}$ & 0.4 & 0.12119 & 0.12109 & 0.12058 \\
\cline { 2 - 5 } & 0.7 & 0.12072 & 0.12088 & 0.12049 \\
\hline
\end{tabular}

먼저, $\mathrm{Al}_{2} \mathrm{O}_{3}$ 나노유체의 열전도도를 측정한 결과가 Table 1 에서와 같이 질량비 농도와 측정 온도에 관계없이 $\mathrm{POE}$ 모유체의 Maker 가 제공한 열전도도와 측정오차 범위 내에서 거의 일정함을 알 수 있었고, $0.1 \%$ 질량비는 실험을 진행하지 않았다.

그러나, 동점성계수의 경우에는 Table 2에 서와 같이 나노입자의 질량비가 감소할수록 모유체 $\mathrm{POE}$ 오일의 동점성계수에 비하여 감 소함을 알 수 있다. 이는 압축기 윤활 등을 고 려할 때 나노유체가 좀 더 우수한 특성을 나 타낼 수 있음을 의미한다.

$\mathrm{TiO}_{2}$ 나노유체의 열전도도는 Table 3에서 와 같이 $0.7 \%$ 질량비에서 측정 온도에 관계 없이 $\mathrm{POE}$ 모유체의 Maker가 제공한 열전도 도와 측정오차 범위 내에서 거의 일정함을 알 수 있었고, 마찬가지로 $0.4 \%$ 와 $0.1 \%$ 질량비 조건에서는 실험을 진행하지 않았다. 또한, $\mathrm{Al}_{2} \mathrm{O}_{3}$ 와 $\mathrm{TiO}_{2}$ 나노유체의 열전도도는 거의 비슷한 값을 가짐을 알 수 있었다.

Table 2. Dynamic viscosity results of $\mathrm{Al}_{2} \mathrm{O}_{3}$ Nanofluids.

\begin{tabular}{|c|c|c|c|c|}
\hline \multicolumn{2}{|c|}{$v\left[\mathrm{~mm}^{2} / \mathrm{s}\right]$} & \multicolumn{3}{|c|}{ 온도 $\left[{ }^{\circ} \mathrm{C}\right]$} \\
\cline { 2 - 5 } & 20 & 30 & 40 \\
\hline \multicolumn{2}{|c|}{$\mathrm{POE}$ maker } & - & - & 83.9 \\
\hline \multirow{2}{*}{$\begin{array}{c}\text { 질 량비 } \\
{[\%]}\end{array}$} & 0.1 & 272.56 & 142.76 & $\begin{array}{c}79.45 \\
(-5.31 \%)\end{array}$ \\
\cline { 2 - 5 } & 0.4 & 280.55 & 145.94 & $\begin{array}{c}81.57 \\
(-2.78 \%)\end{array}$ \\
\cline { 2 - 5 } & 0.7 & 289.21 & 150.80 & $\begin{array}{c}86.21 \\
(+2.76 \%)\end{array}$ \\
\hline
\end{tabular}

Table 3. Thermal conductivity results of $\mathrm{TiO}_{2}$ Nanofluids.

\begin{tabular}{|c|c|c|c|c|}
\hline \multirow{2}{*}{$\mathrm{k}[\mathrm{W} / \mathrm{mK}]$} & \multicolumn{3}{|c|}{ 온도 $\left[{ }^{\circ} \mathrm{C}\right]$} \\
\cline { 2 - 5 } & 20 & 30 & 40 \\
\hline \multicolumn{2}{|c|}{$\mathrm{POE}$ maker } & 0.1204 & 0.1198 & 0.1191 \\
\hline $\begin{array}{c}\text { 질 량비 } \\
{[\%]}\end{array}$ & 0.7 & 0.12037 & 0.12142 & 0.12116 \\
\hline
\end{tabular}

$\mathrm{TiO}_{2}$ 나노유체의 동점성계수는 $\mathrm{Al}_{2} \mathrm{O}_{3}$ 나노 유체용액에 비하여 거의 실험오차 수준에서 유사한 값을 나타냄을 표 4와 같이 알 수 있 다. Table 4에서와 같이 $\mathrm{Al}_{2} \mathrm{O}_{3}$ 나노유체와 동 일하게 나노입자의 질량비가 감소할수록 모 유체 $\mathrm{POE}$ 오일의 동점성계수에 비하여 감소 함을 알 수 있다.

Table 4. Dynamic viscosity results of $\mathrm{TiO}_{2}$ Nanofluids.

\begin{tabular}{|c|c|c|c|c|}
\hline \multirow{2}{*}{$v\left[\mathrm{~mm}^{2} / \mathrm{s}\right]$} & \multicolumn{3}{|c|}{ 온도 $\left[{ }^{\circ} \mathrm{C}\right]$} \\
\cline { 2 - 5 } & 20 & 30 & 40 \\
\hline \multicolumn{2}{|c|}{$\mathrm{POE}$ maker } & - & - & 83.9 \\
\hline \multirow{2}{*}{$\begin{array}{c}\text { 질 량비 } \\
{[\%]}\end{array}$} & 0.1 & 270.75 & 142.50 & $\begin{array}{c}79.10 \\
(-5.73 \%)\end{array}$ \\
\cline { 2 - 5 } & 0.4 & 276.31 & 144.43 & $\begin{array}{c}83.04 \\
(-1.03 \%)\end{array}$ \\
\cline { 2 - 5 } & 0.7 & 284.87 & 147.17 & $\begin{array}{c}85.30 \\
(+1.67 \%)\end{array}$ \\
\hline
\end{tabular}

이러한 결과로부터 모유체를 $\mathrm{POE}$ 오일로 하는 나노유체의 경우에는 열전도도는 거의 동등 수준이며, 점도의 경우에는 낮은 나노입 자의 농도에서 모유체 $\mathrm{POE}$ 오일의 점도보다 낮은 값을 가지므로 압축기 윤활시의 좀더 부 하를 저감할 수 있는 효과를 가질 것으로 판 단된다.

\section{2 나노유체 분산성 측정 결과}

앞서 설명한 바와 같이 질량비 $0.7 \%$ 조건 에서 $\mathrm{Al}_{2} \mathrm{O}_{3}, \mathrm{TiO}_{2}$ 및 $\mathrm{CuO}$ 나노유체를 투명 용기에 담아 24 시간 간격으로 사진을 촬영하 고, 촬영된 사진에서 나노유체의 $\mathrm{RGB}$ 값을 유 
체의 높이를 5등분하여 1-4까지의 위치에 대 하여 분석하였다.

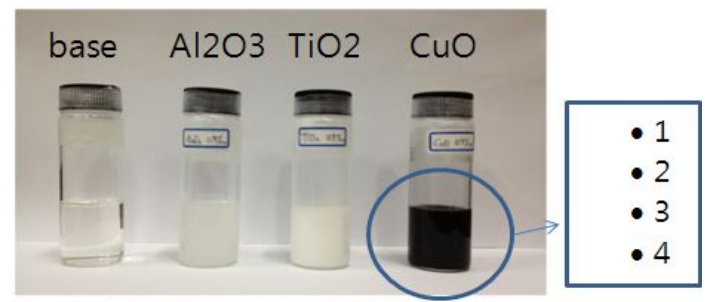

Fig. 1 Photograph of Nanofluids and RGB measuring points.

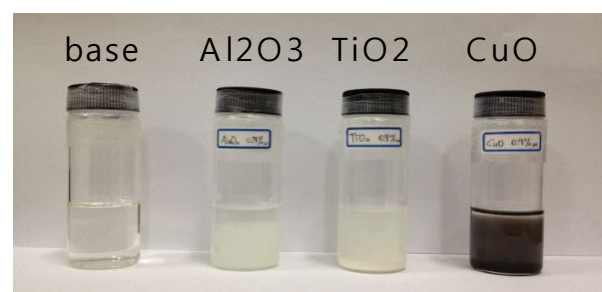

Fig. 2 Photograph of Nanofluids after 28 days.

Fig. 1에서와 같이 모유체 $\mathrm{POE}$ 오일의 색 은 투명하고, 나노입자의 혼합에 의하여 $\mathrm{Al}_{2} \mathrm{O}_{3}$ 용액은 엷은 흰색, $\mathrm{TiO}_{2}$ 는 진한 흰색 그리고 $\mathrm{CuO}$ 용액은 검은색임을 알 수 있다. 또한, Fig. 2에서와 같이 나노입자들이 시간이 흐름에 따라 침전하는 것으로 나타나고, 이러한 침전의 상태를 $\mathrm{RGB}$ 값으로 하여 정량적을 분석하고자 한 것이 다. RGB 값들은 완전 흰색인 경우 모두 255의 값 을 나타내고, 완전 검은색이 0 의 값을 나타낸다. 질량비 $0.7 \%$ 의 나노유체들은 먼저 육안으로 확인하면, $\mathrm{TiO}_{2}$ 가 2 일째부터, $\mathrm{CuO}$ 는 9 일째부터, 그리고 $\mathrm{Al}_{2} \mathrm{O}_{3}$ 가 15 일째부터 침전이 시작됨을 알 수 있었다. 이러한 침전 특성에 대한 나노입자들 의 분자량(Table 5. 참조)에 의한 영향을 고려하 면, 이러한 침전특성과 무관함을 알 수 있다.

Table 5. Molecular weight of each Nanofluids

\begin{tabular}{|c|c|c|c|}
\hline 나노입자 & $\mathrm{Al}_{2} \mathrm{O}_{3}$ & $\mathrm{TiO}_{2}$ & $\mathrm{CuO}$ \\
\hline $\begin{array}{c}\text { 분자량 } \\
{[\mathrm{g} / \mathrm{mol}]}\end{array}$ & 102.0 & 79.9 & 79.5 \\
\hline
\end{tabular}

측정된 $\mathrm{RGB}$ 값들을 실험 경과 날짜에 따 라 정리하면, 용액의 색이 흰색인 $\mathrm{TiO}_{2}$ 용액 의 경우에 Fig. 3 과 같이 가장 위쪽인 1 번 위 치부터 2 번과 3 번 위치 모두에서 $\mathrm{RGB}$ 값이 감소하는 경향은 나타나지만 명확하게 육안 으로 확인되는 침전의 특성을 나타내지 못하 였다. $\mathrm{Al}_{2} \mathrm{O}_{3}$ 용액도 유사한 결과를 나타내는 데, 사진 촬영을 통해 $\mathrm{RGB}$ 분석을 위해서는 배경색이 필요한데, 최대한 배경색의 영향을 배제하기 위한 흰색배경이 용액의 색과 유사 하여 오히려 RGB 값으로는 거의 명확한 차 이에 대한 측정이 어려운 것으로 판단된다.

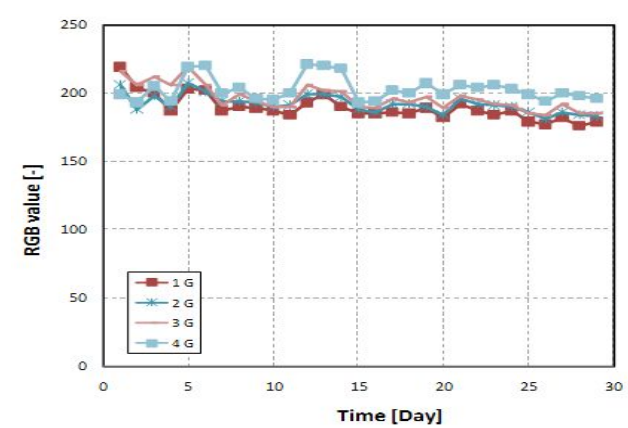

Fig. $3 \mathrm{RGB}$ value with time of $\mathrm{TiO}_{2}$ Nanofluids.

그러나, $\mathrm{CuO}$ 의 경우에는 Fig. 4에서와 같 이 육안 관찰 기록과 동일하게 거의 9 일째부 터 1 번 위치에서 초기 검은색(RGB값 0$)$ 에서 엷은 검은색으로 변하면서 $\mathrm{RGB}$ 값이 증가하 고, 마찬가지로 2-3위치도 점점 옅은 검은색 으로 변하면서 $\mathrm{RGB}$ 값이 증가하고 있다.

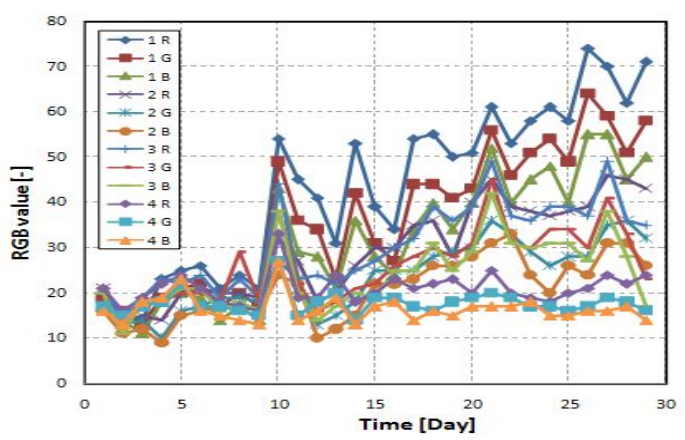

Fig. 4 RGB value with time of CuO Nanofluids. 
따라서, 나노유체의 용액 침전 특성은 흰색이 아닌 경우에는 RGB값의 측정에 의해서도 명확하 게 경향과 특성을 분석할 수 있음을 알 수 있다.

이러한 결과와 함께 가시적인 침전 특성을 명확하게 정량적으로 제시하기 위하여 용기 내의 초기 용액높이 $\left(\mathrm{h}_{\mathrm{o}}\right)$ 와 시간에 따라 침전 되면서 용액의 투명해지는 높이 $\left(\mathrm{h}_{\mathrm{sink}}\right)$ 를 촬영 된 사진으로부터 측정하였다.(Fig. 5 참조) $\mathrm{TiO}_{2}$ 용액의 침전높이가 포화되고, $\mathrm{CuO}$ 도 동 일한 특성에 도달하면 실험을 중지하고, 이어 2차로는 사이클 적용시 압축기의 On-Off 운전 특성을 적절하게 만들어주기 위하여 용액용기 를 손으로 가볍게 10 여 차례 흔들어준 다음 다 시 시간 경과에 따라 동일한 방법으로 침전높 이를 측정하였다. 2 차 실험 후에는 나노유체 제작 방법에 의거하여 소니케이터에서 소닉을 실시한 후 다시 3 차 침전실험을 수행하였다.

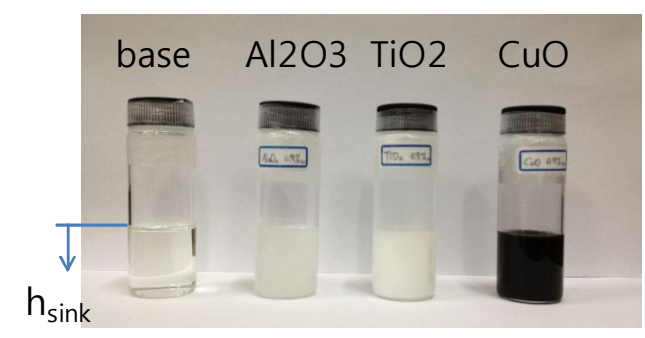

Fig. 5 The method for measure the sinking height.

Fig. 6a)에서와 같이 1차 실험에서는 가시 적으로 나타나는 침전의 특성이 정확하게 정 량적으로 침전높이의 경향과 일치하고 있음 을 알 수 있다. 2차 실험에서는 모든 유체가 침전이 더 빠르게 진행됨을 알 수 있다. $\mathrm{TiO}_{2}$ 는 2 일째부터, $\mathrm{CuO}$ 는 3 일째부터, 그리고 $\mathrm{Al}_{2} \mathrm{O}_{3}$ 는 5일째부터 시작되었다. 소닉 이후에 다시 측정된 3 차 실험에서도 2 차 실험과 거의 유사한 침전 특성을 나타내었다.

이러한 실험적인 특성을 분산안정성에 대한 이론식인 식(1)을 이용하여 Table 6과 같이 나노 입자와 모유체 오일의 물성들을 이용(모유체 밀

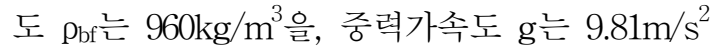

로, 온도는 상온을 대입) 하여 평가하였다.

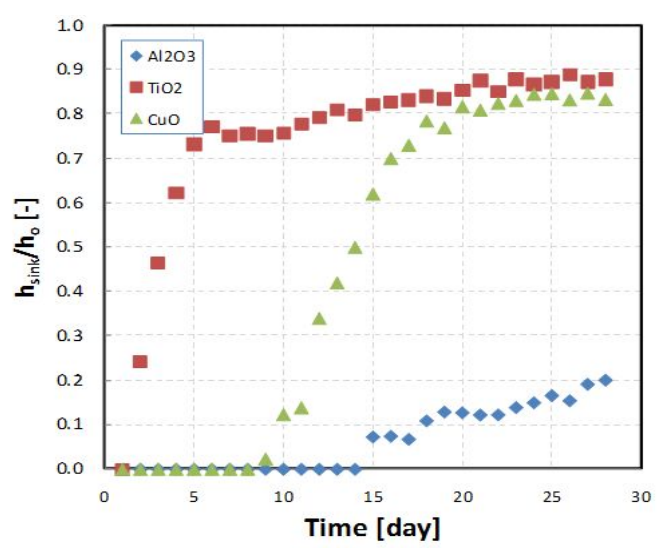

a) The first experimental results

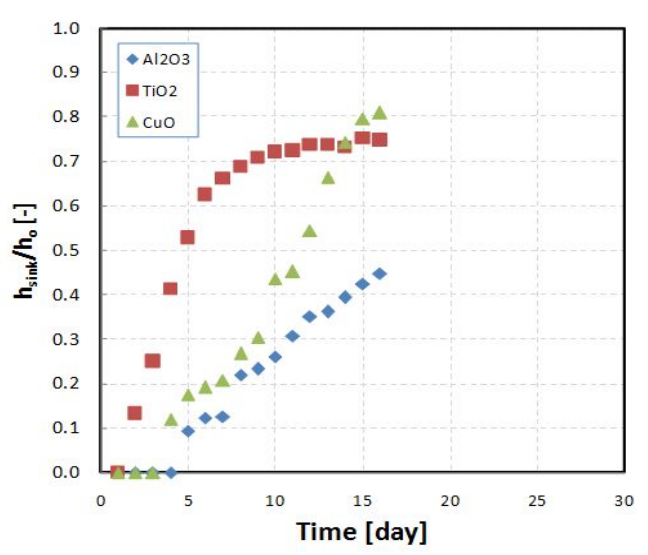

b) The second experimental results

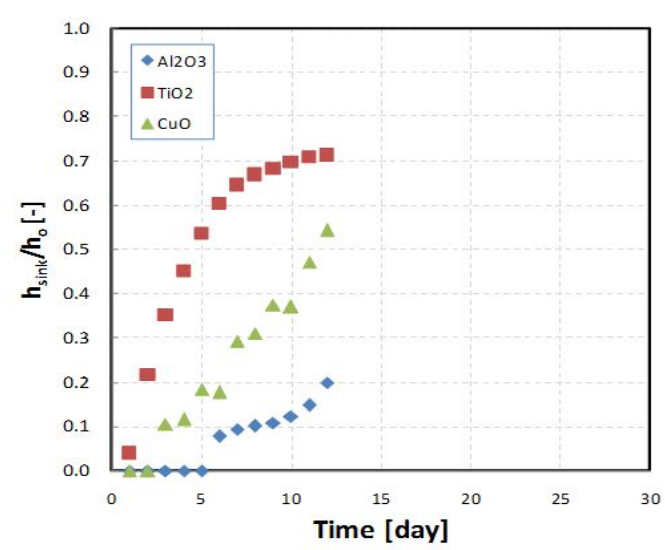

c) The third experimental results

Fig. 6 The sinking height results with time. 
Table 6. Dispersion characteristics(G) calculation results and the properties used for that calculation

\begin{tabular}{|c|c|c|c|}
\hline 나노입자/물성 & $\mathrm{Al}_{2} \mathrm{O}_{3}$ & $\mathrm{TiO}_{2}$ & $\mathrm{CuO}$ \\
\hline $\mathrm{r}[\mathrm{m}]$ & 102.0 & 79.9 & 79.5 \\
\hline $\mathrm{\rho}_{\mathrm{p}}\left[\mathrm{kg} / \mathrm{m}^{3}\right]$ & 5483 & 4260 & 4239 \\
\hline \hline $\mathrm{G}[-]$ & $\begin{array}{c}8.061 * 10^{-8} \\
{[\text { 기준] }}\end{array}$ & $\begin{array}{c}4.045 * 10^{-7} \\
{[5.02 \text { 배] }}\end{array}$ & $\begin{array}{c}1.292 * 10^{-5} \\
{[31.93 \text { 배] }}\end{array}$ \\
\hline
\end{tabular}

전체적으로 $\mathrm{G}$ 값은 1 보다 매우 낮아 분산성 은 나쁘지 않은 것으로 나타나고, 값이 가장 낮은 $\mathrm{Al}_{2} \mathrm{O}_{3}$ 를 기준으로 하면 $\mathrm{CuO}$ 가 분산성 이 약 31 배 정도 떨어지는 것으로 나타내었 다. 세가지 나노입자의 이론적 분산성은 실험 결과와 마찬가지로 $\mathrm{Al}_{2} \mathrm{O}_{3}$ 가 상대적으로 가장 우수한 것으로 나타났다.

이러한 결과들로부터 정확하게 냉동사이클 에 적용될 때의 명확한 침전 특성을 알 수는 없지만, 본 연구에서 최종적으로 선택하고자 하는 모유체가 $\mathrm{POE}$ 오일인 경우에 분산성이 가장 우수한 나노입자는 $\mathrm{Al}_{2} \mathrm{O}_{3}$ 인 것으로 판 단할 수 있다.

다만, 압축기의 실제 운전 상태에 대해서는 실제 사이클에서의 운전조건에서 판단할 수 있는 방법에 대한 명확한 추가적인 연구가 필 요한 실정이다.

\section{4. 결 론}

본 연구에서는 지금까지 명확하게 측정되 어 제시되지 않았던 모유체 $\mathrm{POE}$ 오일에 세 가지 나노입자 $\left(\mathrm{Al}_{2} \mathrm{O}_{3}, \mathrm{TiO}_{2}\right.$ 및 $\left.\mathrm{CuO}\right)$ 를 적용 한 나노유체의 열전도도 $(\mathrm{k})$ 와 동점성계수 $(\mathrm{v})$ 를 온도 $\left(20^{\circ} \mathrm{C}-40{ }^{\circ} \mathrm{C}\right)$ 및 중량비 $(0.1 \%-0.7 \%)$ 별 로 측정하였다. 이와 아울러, 실제 냉동사이 클에 적용하기 위해 우선적으로 검토되어져 야 하는 나노유체의 분산성을 단순한 실험적 방법으로 평가하여 사이클 운전 상태를 고려 하지 않고 최적의 나노입자를 선정하여 그 결
과를 제시하였다.

(1) $\mathrm{Al}_{2} \mathrm{O}_{3}$ 와 $\mathrm{TiO}_{2}$ 나노입자를 가진 나노유체 의 열전도도는 모유체의 열전도도와 온 도와 농도에 상관없이 거의 유사한 것으 로 나타났다. 또한, 동점성계수는 나노입 자의 질량 농도비가 낮은 조건에서 모유 체의 동점성계수에 비하여 낮아지는 특 성을 보여주었다.

(2) $\mathrm{Al}_{2} \mathrm{O}_{3}$ 와 $\mathrm{TiO}_{2}$ 나노유체의 열전도도와 동 점성계수는 거의 실험오차 수준내에서 동등한 물성을 가지고 있음을 알 수 있다.

(3) 동일한 조건에서의 분산안정성은 $\mathrm{Al}_{2} \mathrm{O}_{3}$, $\mathrm{TiO}_{2}$ 및 $\mathrm{CuO}$ 의 세가지 나노유체 중에서 $\mathrm{Al}_{2} \mathrm{O}_{3}$ 나노유체가 가장 우수한 것으로 판 단되었다.

(4) 측정된 열물성과 분산안정성을 고려하면 세가지 나노입자 중에서 입자는 $\mathrm{Al}_{2} \mathrm{O}_{3}$ 를, 그리고 농도는 낮은 $0,1 \%$ 정도가 사이클 적용의 최적 조건인 것으로 판단된다. 다 만, 실제 냉동사이클 운전조건에서의 실 험을 통한 검증은 반드시 필요한 절차일 것이다.

\section{후 기}

본 연구는 산업기술연구회 협동연구사업 (B551179-11-02-00)의 지원으로 수행된 결 과임

\section{References}

1. Saidur R., Kazi S.N., Hossain M.S., Rahman M.M., Mohammed H.A., A Review of the Performance of Nanoparticles Suspended with Refrigerants and Lubricating Oils in Refrigeration Systems, Renewable and Sustainable Energy Reviews, 2010, Vol. 15, pp. 310-323.

2. Kim H., Kim J., Kim M., Experimental Study 
on CHF Characteristics of Water- $\mathrm{TiO}_{2}$ nano-fluids, Nuclear Engineering and Technology, 2006, Vol. 38, No. 1, pp. 61-68.

3. Kim H., Kim J., Kim M., Effect of Nanoparticles on CHF Enhancement in Pool Boiling of Nano-fluids, Int. J. of Heat and Mass Transfer, 2006, Vol. 49, pp. 50705074.

4. The report, Investigation of Heat and Flow Characteristics of Nanofluids and Safety Guarantee Technology, 2010.

5. Hwang, Y., Park, H., Lee, J.K., An Experimental Study on Thermal Conductivity and Stability of Nanofluids, Proceedings of KSME Spring Conference, 2005, pp. 2388- 2393.

6. Lee, K.I., Yang, S.W., Kim, H.J., Jung, J.H., Kang, Y.T., An Experimental Study on the Distribution Stability of Binary Nanofluids of $\mathrm{H}_{2} \mathrm{O} / \mathrm{LiBr}$, Proceedings of KSME Spring Conference, 2006, pp. 2325-2330.

7. Kwon, H.L, Hwang, K.S., Jang, S.P., Thermal Conductivity and Viscosity of Distilled Water/Commercial Coolant Based $\mathrm{Al}_{2} \mathrm{O}_{3}$ Nanofluids, Proceedings of KSAE, 2011, Vol. 19, No. 3, pp. 130-137.

8. Jung, T.Y., Koo, J., Kang, Y.T., Model for the Dispersion Stability of Nanofluids, Proceedings of KSME Spring Conference, 2010, pp. 36-37. 